\title{
JUNIOR HIGH SCHOOL STUDENTS' LIVED EXPERIENCES OF LEARNING ENGLISH USING BUSUU
}

\author{
Vinindita Citrayasa \\ Universitas Atma Jaya Yogyakarta, Indonesia \\ E-mail: vinindita.citrayasa@ uajy.ac.id
}

APA Citation: Citrayasa, V. (2019). Junior high school students' lived experiences of learning English using Busuu. Indonesian EFL Journal, 5(2), 85-92. doi: 10.25134/ieflj.v5i2.1900.

Published: 01-07-2019

\begin{abstract}
Researches on MALL mostly focus on how learning by using mobile phones gives significant effect on second/ foreign language skills. However, only few which focus on their lived-experiences of learning English using their smart phones anywhere outside their class and anytime outside their school time that can reveal meanings related to their awareness, beliefs, and actions. This research is then aimed at describing and interpreting the students' lived experience of using a mobile application namely Bussu for learning English. The study is a hermeneutic phenomenology study which focuses on the description and interpretation of the students' lived experiences of using Busuu to learn English. There were two participants interviewed using in-depth interviews and the data was in the form of texts. The result shows the participants' lived experiences showed some empirical meanings: ubiquitous learning, fun learning, and useful English learning assistant. This study also reveals the finding of transcendent meaning that Busuu encouraged them to become more autonomous learners.
\end{abstract}

Keywords: Busuu; English learning; junior high school students; lived experiences; MALL.

\section{INTRODUCTION}

Technology has been developing and producing many devices that are helpful in assisting learners to learn English. Smart phone is one technology product designed with new and smart functions such as educational application. There are many applications for language learning that are designed and developed (Godwin-Jones, 2011; Chang \& Hsu, 2011; Chen \& Chung, 2008; Fallahkhair, Pemberton \& Griffiths, 2007; Huang, Huang, Huang, \& Lin, 2012). Its portability gives effect to a new way of learning: ubiquitous and personal learning. The users can download and install many language learning applications (both free and purchased) such as language courses, flash cards, and dictionaries which are designed by third part apps companies: Android and Apple from Google Play Store. The learning process then happens not only inside classroom but also outside classroom; not only in school hours, but also in their spare time (Cilesiz, 2011; Kukulska-Hulmes, 2012; Brick, 2015).

There are positive results studies on how MALL (mobile assisted language learning) gives positive results and significant effect on second/foreign language skills such as vocabulary learning (Başoğlu \& Akdemir, 2010; Agca \& Özdemir, 2013; Liu, 2014), extensive reading (Lin, 2014), reading development of young learners (Lan, Sung, \& Chang, 2013), grammar accuracy (Baleghizadeh \& Oladrostam, 2010; Guerrero, Ochoa, \& Collazos, 2010; Nah, 2010), listening (Demouy \& KukulskaHulme, 2010; Azar \& Nasiri, 2014), pronunciation (Segaran, Ali \& Hoe, 2014), and mobile dictionary integration (Rahimi \& Miri, 2014). Mobile learning can engage the language classroom (Zhang, 2013).

The researches or studies mentioned previously are done to measure the students' achievement in using MALL for their improvement in learning, however only few which focus on their lived-experiences which can reveal meanings related to their awareness, beliefs, and actions. The concept of experience in phenomenology and suggestion of experience with technology as a construct for educational technology research is proposed as important research to be done (Cilezis, 2011). The purpose of the 
inquiry is to increase the understanding of technology's influence on individuals, societies, and education and to contribute to unlocking potentials for research at the core of educational technology as well as to help create new lines of inquiry. It attempts to highlight several potential research areas in educational technology that would benefit from building on a phenomenological concept of experience and utilizing phenomenology as the theoretical and methodological framework since phenomenology is concerned with uncovering and describing the essence of human experiences. It has potential to offer valuable insights about the use of technology in teaching and learning.

The goal of this research is to describe and interpret the junior high school students' meaningful experiences in using one of language learning application, Busuu, to assist them learning English. The description and the interpretation will lead to another goal which is to improve higher efficiency and better understanding of the value got from the participants lived experience. Through this hermeneutic phenomenology research, the junior high school students' experiences are going to be unveiled, described and interpreted in order to discover the meaning of learning English with Busuu to students.

\section{METHOD}

This study implemented a phenomenological study which is a qualitative research concerning more about the verbal data of description and interpretation. Its setting is a real world setting which is observed in order to gather the participants' view of their meaningful lived experiences. In this study, there are two students of junior high school who used an English learning mobile application downloaded from Google Play. The in-depth interviews were done and the obtained data which was in the form of texts was transcribed and interpreted to seek the meaning of their experiences towards the phenomenon. The interview was a snowballing interview, which questions of the interview were developed naturally following the directions of the interview. The questions were not totally set but they came up as the results of the interviewees' previous answers.

The data was analyzed using six steps proposed by Creswell (2012). There were six steps done in analyzing the data of this study. The first step was preparing and organizing the data for analysis. The data from the indepth interviews were transcribed from the recorded interview. The second step was exploring and coding the texts. The purpose of coding was to seek and to build themes and the themes were categorized. The data was then described and interpreted to develop the understanding of learning English using Busuu.

\section{RESULTS AND DISCUSSION}

The following is the discussion of meanings interpretation of the participants' lived experiences of learning English using Busuu. The interpretations below were bracketed under the pre-figured themes: empirical meanings consisting three themes and transcendent meaning. The themes are ubiquitous learning, useful English learning assistant, and fun learning assistant. The explanation for each theme is discussed below.

\section{Ubiquitous English learning}

The study revealed that students were aware that they experienced learning with technology which took place not only inside classroom. The technology created a chance for them to experience the process of learning outside of their classroom and out of his English class hours. The participants of this research mostly experienced the type of learning inside class room during school hours and learning with their private English teachers at home. The notion "anytime" mentioned by the participants is not referred to only his hours outside of school hours but also his spare time when the students have no other options to spend the time besides gaming.

There is a change of learning action when he uses Визиu. He interacts with his smart phone for playing games anymore but he 
plays with Bиsиu for learning. That moment has developed a new situation of learning English. The core attraction of MALL is the potential to turn such dead time into using time. Dead time here is defined as time you have when you have nothing to do. The possibility of learning in your free time may happen at your free time when you can use that time to study with your smart-phone. The point to emphasize is that learners have more opportunities to use their time outside classroom to study (Brick \& Cervi-Wilson, 2015).

\section{Fun English learning}

"Busuu is fun!" That was the statement that both participants said when they were asked to tell about their feelings when they interact with the application. They sound excited to tell their experiences oh how fun Busuu was. The learning could be that fun since Busuu offers motivating features such as game combined with social networking, garden or language courses and materials, berries and study reminders. There are 150 various topics that learners can choose to learn in this application. Besides the various types of materials, there are various and fun quizzes to accomplish. The other features such as pictures and various types of learning materials and tasks or activities and berries (as the learning rewards) are the interesting parts that made them happy to keep learning. The features trigger and engage his desire and excitement to learn and play with it.

Besides vocabulary task, there is listening task, matching task, and completing dialogue tasks. Wherever they finished their tasks, they would get berries. The participants mostly considered the rewards as motivating and fun features. These made them experienced the feeling of an enjoyment in learning English as this kind of learning method is different with other learning methods. Various types of materials, types of learning activities, and the berries reward, there are other features such as the app's interface, pictures and animation that create fun and entertaining learning shows a change type of learning nowadays. This kind of situation of learning is a typical shift of learning in the digital age of using technology where learning as torture becomes learning as fun (Tapscott, 2009). Learning as fun encourages learners to be more motivated (Looi et al., 2010). The feeling of enjoyment engages and fosters the participants keep learning until getting 10,000 berries. The experience of fun learning with Виsuu created a personal preference over it. One participant stated that he preferred to learn English with Busuu than to learn from books for he considered that learning with books is less interesting and books are more expensive.

\section{Useful English learning assistant}

Busuu means a helpful assistance for learning. It helped the students a lot to improve their English skills especially when their teachers are not around. Both students had the same intention of enriching their knowledge and improving their English skills. Their intention and expectation meets with the features of English skills learning that Busuu offers. The students experienced the assistants to learn the basics of English vocabulary, listening, speaking, pronunciation and writing. They experienced an improvement in listening, pronunciation, and word spelling. The improvement itself is shown as a result as Виsu facilitates the students with the activities and quizzes to memorize words and words spelling. It was also so helpful in helping students to more focus on learning. One student stated that it was important to be focused on what he was learning that it would be easier for him to understand. Pertained to the pronunciation skill improvement, Busuи was perceived helping students effectively. When using translator machine, the students got the meaning only. However, Busuu provides both meaning and how to pronounce it well.

Mobile learners perceived more and preferred learning with mobile phones compared with paper and computer-based lessons to learn vocabulary (Thornton \& Houser, 2005 in Kim \& Kwon, 2012). In the computer era, education has been reconceptualized around the construction of knowledge through information processing, 
modeling, and interaction (Sharples, 2006). Besides, Busuu is helpful in providing space for students to learn directly from native speakers. The students are exposed to interact, to be exposed and to be involved in authentic tasks in learning speaking with native speakers. It allows rapid development of speaking, listening, reading, and writing skills through the individualized language learning activities synchronously (happening right now) and/asynchronously. Through more opportunities to learn which Busuu creates various topics provided there, the students gained more access and time again and again to revisit his understanding in different contexts and ways of learning. Furthermore, the students got more time and chances to experience learning repetition which empower them to learn better and to understand better. This is in line with a study stating that the mobile application enables learners to learn on the move which means the students can learn across the time, revisiting knowledge that was gained earlier in a different context, and more broadly (Vavoula \& Sharples, 2002).

\section{Transcendent meaning}

The meaning of learning English with Busuu for the participants was not merely perceived only empirically in the themes of ubiquitous, fun, and useful learning that could them to develop their English skills but also transcendentally which related to their autonomous character. Since the students got more chances to learn individually, they got more opportunities to deal with situations which require them to make decision and to take charge of any possible responsibility. One decision that both had made was related to their actions to choose to study or to play games. They had freedom to choose moreover they had a total freedom in the time and situation when they were not required to study. When learners are positioned in the situation where they do self study with the help of their mobile phones, they take charge of their own learning responsibilities, choices, and decisions. Therefore, the assistance or the help of mobile learning triggers the learners' autonomy in learning language which means that the learners accepts responsibility for his/ her learning (Chang, 2007).

Being aware of the importance of Learning English, the students chose to make use Busuu as a learning resource which is believed able to role as a facility to learn English since they realize that Google Translator is not enough to improve his English language skills. The student positioned himself as a centre of learning where he took a decision by his own initiative to make use Busuu as a learning resource. The learners become the center of learning, since they are able to make use their devices to get the resources for learning (Macaskill \& Taylor, 2010). That shows a characteristic of autonomous learners. As stated by Paul \& Elder (2008), autonomy is the freedom and ability to manage one's own affairs, which entails the right to make decisions as well. There are learners' actions to direct and control their thinking, author their beliefs, values, and ways of thinking.

Another characteristic of autonomy reflected on the experiences of using Busuu is that the students are able to be more aware of their language learning process and progress. Nation \& Macalister (2010) states that independent and effective learner that they show their capabilities to know how to learn language, to monitor, and to be aware of their language learning process and progress. The experience of learning using that technology can be interpreted showing the students' independence in learning while the teachers are not around instructing to learn with Busuu continually. The feeling of enjoyment in learning itself triggers the autonomous character in him. His independence in learning reflects one character of autonomy which a learner shows an action of learning without any instruction or guidance of anyone around him such as teacher who are not always able to be around the learners (Nosratinia \& Zaker, 2013).

Other characteristic of an autonomous learner which the students develop during his learning process with Busuu is persistency. Myartawan \& Suharmantoet

(2013) 
characterizes persistency as an action of moving on continuously on despite the problems and challenges that learners face without waiting for helps from others. A study reveals that learning with smart phones encourages students to have more effort in their private learning, in terms of the length of time they spent studying (Leis et al., 2015). For the participant, the efforts and desire to learn should be encouraged. He felt of being challenged by Виsuи in a way that the application could encourage to keep trying and to not easily give up.

Continuously moving on despite the problems and challenges without waiting for helps from others is a sign of one character of autonomy which is persistency (Myartawan, 2013). The students experienced the various types of moments of ups and downs in learning with Busuu, when he faced a type of learning which was not easy. He dealt with difficult tasks and quizzes, especially when started to level up to intermediate level. The interview revealed the participant's story when he felt of being challenged instead of being discouraged.

The students were aware of the importance of English learning. Before using Busuu, he used his free time for being updated on his social media accounts and playing games in his computer and smart phone. His daily schedule for his free time changed after using Виsuu. Since he considered that learning with Busuu was more important than playing games, he chose to open the application and used his free time to learn instead of dealing with something which could be considered as more fun. His action reflects another character of autonomy which is resourceful. Resourcefulness is related to the intention to make decision and action in order to solve problems. Learners are able to make learning as the main priority over the other activities which are considered more fun (Myartawan et al., 2013).

The other changes in the students which happen after using Busuu did not only happen in their activity at their free time but also in the mindset change. To choose other activities over to keep learning English using

\section{https://journal.uniku.ac.id/index.php/IEFLJ/index}

Busuu was also a free was a free decision to choose. Based on the participant's story, he experienced an ability to reflect his freedom, power, and change over his life. Taking control over learning management means they are able to plan, to organize, and to evaluate their learning and he states that those are observable through their behavior (Benson, 2001).

It can be noted that learning with Busuu heightens the learners' autonomy through various resources and tools for language learning (Cho, 2009; Lee, 2010; Kim \& Kwon, 2012). Using Busuu as a resource for learning causes a tendency of being autonomous.

\section{CONCLUSION}

This study attempts to reveal the meanings of English learning using Busuu to junior high school grade VII. Two participants shared their lived experiences of using Виsuи to learn English and assigned some meanings. Based on the participants' lived experience, it can be noted that Busuu has some benefits for learning English which can take place not only in classroom as they experience so far, but also at their free time outside of their learning schedule. Виsuи could facilitate learners to turn their dead time and free time to a kind of fun circumstance for learning. The less tensed learning can encourage students to learn more.

Through their lived experiences, it can be noticed Busuu provides tasks and quizzes which are able to facilitate students to improve their language skills and one of the participant stated that he got better score. Further, an experimental research can be done to reveal the further implication of learning English with Busuu to improve their language skills.

\section{REFERENCES}

Agca, R. K., \& Özdemir, S. (2013). Foreign language vocabulary learning with mobile technologies. Journal of 2 nd World Conference on Educational Technology Researches, 83, 781-785. Retrieved on December 16, 2019 from www.ff.cuni.cz/FF1289-version1-kr.pdf.

Azar, A. S., \& Nasiri, H. (2014). Learners' attitudes toward the effectiveness of mobile assisted 
Junior high school students' lived experiences of learning English using Busuu

language learning (MALL) in L2 listening comprehension. International Conference on Current Trends in ELT, 98, 1836-1843. Retrieved on January 12, 2019 from https://www.arcjournals.org/pdfs/ijsell/v2i11/5.pdf.

Baleghizadeh, S., \& Oladrostam, E. (2010). The effect of mobile assisted language learning (MALL) on grammatical accuracy of EFL students. MEXTESOL, 34(2), 1-10. Retrieved on December $\quad 15, \quad 2015$ from http://www.efltasks.org.

Başoğlu, E. B., \& Akdemir, Ö. (2010). A comparison of undergraduate students' English vocabulary learning: Using mobile phones and flash cards. TOJET: The Turkish Online Journal of Educational Technology, 9(3), 1-7.

Benson, P. (2001). Teaching and researching autonomy in language learning. London: Longman.

Benson, P., \& Reinders, H. (2011). Beyond the language classroom. Basingstoke: Palgrave Macmillan.

Brick, B., \& Tiziana, C. (2015). Technological diversity: A case study into language learners' mobile technology use inside and outside the classroom. Retrieved on April 25, 2015 from research-publishing.net.

Chang, C. K., \& Hsu, C. K. (2011). A mobile-assisted synchronously collaborative translationannotation system for English as a foreign language (EFL) reading comprehension. Computer Assisted Language Learning, 24(2), 155-180.

Chen, N. S., Hsieh, H., \& Kinshuk, S. W. (2008). Effects on short-term memory and content representation type on mobile language learning. Language Learning and Technology, 12(3), 93113.

Cheng, S. C., Hwang, W. Y., Wu. S. Y., Shadiev, R., $\&$ Xie, C. H. (2010). A mobile device and online system with contextual familiarity and its effects on English learning on campus. Educational Technology and Society, 13(3), 93 -109.

Cilesiz, S. (2011). A phenomenological approach to experiences with technology: Current state, promise, and directions for research. Educational Technology Research and Development 59(4), 487-510. Retreived on July 30, 2019 from http.jstor.org/stable/41414955.

Creswell, J. W. (2012). Educational research in classrooms and schools: A manual of materials and methods. London: Harper \& Row Ltd.

Demouy, V., Eardley, A., Kukulska-Hulme, A., \& Thomas, R. (2009). The L120 mobile project. Proceedings Mobile Learning and Autonomy in Second Language Acquisition. Retrieved on December 16, 2014 from http://oro.open.ac.uk.

Fallahkhair, S., Pemberton, L., \& Griffiths, R. (2007). Development of a cross-platform ubiquitous language learning service via mobile phone and interactive television. Journal of Computer Assisted Learning, 23(2), 321-325.

Guerrero, L., Ochoa, S., \& Collazos, C. (2010). A mobile learning tool for improving grammar skills. Procedia Social and Behavioral Sciences, 2(2), 1735-1739. Retrieved on December 16, 2014 from http://users.dcc.uchile.

Hsu, L. (2012). English as a foreign language learners' perception of mobile assisted language learning: A cross-national study. Computer Assisted Language Learning, 26(3), 1-17.

Huang, Y. M., Huang, Y. M., Huang, S. H., \& Lin, Y. T. (2012). A ubiquitous English vocabulary learning system: Evidence of active/passive attitudes vs. usefulness/ease-of-use. Computers and Education, 58(1), 273-282.

Kim, H., \& Kwon, Y. (2012). Exploring smartphone applications for effective mobile-assisted language learning. Multimedia-Assisted Language Learning, 15(1), 31-57.

Kukulsak-Hulme, A., \& Shield, L. (2008). An overview of mobile assisted language learning: Can mobile devices support collaborative practice in speaking and listening? ReCALL, 20(3), 271-289.

Kukulska-Hulme, A., \& Traxler, J. (2005). Mobile learning: A handbook for educators and trainers. London: Routledge.

Lan, Y., Sung, Y., \& Chang, K. (2013). From particular to popular: Facilitating EFL mobilesupported cooperative reading. Language Learning \& Technology, 17(3), 23-38.

Leis, A., Akihiko, T., \& Cooke, S. D., (2015). Smartphone assisted language learning and autonomy. International Journal of ComputerAssisted Language Learning and Teaching, 5(3), 75-78.

Lin, C. (2014). Learning English reading in a mobileassisted extensive reading program. Computers \& Education, 78(2), 48-59.

Liu, J., Yu, S., \& Ran, M. (2008). Research in the communicative mobile English learning model. Fifth IEEE International Conference of Wireless, Mobile, and Ubiquitous Technologies in Education.

Liu, P., \& Chen, C. (2014). Learning English through actions: A study of mobile-assisted language learning. Interactive Learning Environments, 23(2), 1-14.

Looi, C., Seow, P., Zhang, B., So, H., Chen, W., \& Wong, L. (2010). Leveraging mobile technology for sustainable seamless learning: A research agenda. British Journal of Educational Technology, 41(2), 154-169.

Macaskill, A., \& Taylor, E. (2010). The development of a brief measure of learner autonomy in University Students. Studies in Higher Education, 35(3), 351-359.

Myartawan, I. P. N. G., \& Suharmanto, M. A. F. 
Indonesian EFL Journal (IEFLJ)

Volume 5, Issue 2, July 2019

(2013). The correlation between learner autonomy and English proficiency of Indonesian EFL college learners. TEFLIN Journal, 24(1), 63- 81.

Nah, K. C. (2010). The use of the internet through mobile phones for EFL listening activities. Proceedings Applied Linguistics Association of Korea 2010 Annual Conference, 197-205.

Rahimi, M., \& Miri, S. S. (2014). The impact of mobile dictionary use on language learning. International Conference on Current Trends in ELT, 98(1), 1469-1474.

Segaran, K., Ali, A. Z., \& Hoe, T. W. (2014). Usability and user satisfaction of 3d talking-head mobile assisted language learning (MALL) app for non-native speakers. WCETR 2013, 131, 410. Retrieved on January 12, 2019 from https://core.ac.uk/download/pdf/81124817.pdf.

Shanmugapriya, M., \& Tamilari, A. (2013). Design and development of mobile assisted language learning (MALL) application for English language using android push notification services. International Journal of Research in
p-ISSN 2252-7427, e-ISSN 2541-3635

https://journal.uniku.ac.id/index.php/IEFLJ/index

Computer and Communication Technology, 2(6), 329-338.

Sharples, M., Taylor, J., \& Vavoula, G. (2006). A theory of learning for the mobile age. The Sage Handbook of E-learning Research, 221-247.

Thornton, P., \& Houser, C. (2005). Using mobile phones in English education in Japan. Journal of Computer Assisted Learning, 21(3), 217-228.

van Manen, M. (1997). Researching lived experience: Human science for an action sensitive pedagogy. Canada: University of Western Ohio.

Vavoula, G. N., \& Sharples, M. (2002). KLeOS: A personal, mobile, knowledge, and learning organization system. In M. Milrad, U. Hoppe, \& K. Kinshuk (Eds.), Proceedings of the IEEE International Workshop on Mobile and Wireless Technologies in Education (pp. 152-156).

Zhang, L. (2013). Mobile phone technology engagement in EFL classroom. International Conference on Software Engineering and Computer Science. Retrieved on March 30, 2019 from http.jstor.org/stable/41414955. 


\section{Vinindita Citrayasa}

Junior high school students' lived experiences of learning English using Busuu 